\title{
Selection and Gradation of Materials: A Review of the Second Semester's English Materials of Preparatory Year, Najran University
}

\author{
Mohammad Nazim $^{1} \&$ Jalal Ahmad $^{1}$ \\ ${ }^{1}$ Najran University, Saudi Arabia \\ Correspondence: Mohammad Nazim, Najran University, Saudi Arabia. E-mail: nazimspeaking@yahoo.co.in
}

Received: June 13, 2017 Accepted: July 17, 2017 Online Published: July 26, 2017

doi:10.5539/ijel.v7n5p196 URL: http://doi.org/10.5539/ijel.v7n5p196

\begin{abstract}
This study was conducted to review the process of selection and gradation of English materials and to explore their effectiveness and appropriateness for the students of second level, at PYP (Preparatory Year Program), Najran University. It also reviewed various factors responsible for the constant change in English materials at PYP. A questionnaire consists of 11 questions along with two semi structured interview questions was distributed among 15 teachers. Data collected from participants was analyzed using simple excel and SPSS. The results revealed that the material was not appropriately selected and graded, and the lessons and the exercises in the materials were not useful as per the students' academic needs. Furthermore, majority of the respondents agreed that the materials did not cater to achieve desired learning outcomes. The study, in the end, recommends some possible measures to be taken into consideration while selecting and grading the materials to achieve the desired goal.
\end{abstract}

Keywords: English materials, level 2 students, preparatory year program, selection and gradation process etc.

\section{Introduction}

Course materials are indispensable tools that correspond closely to the aims and objectives of a teaching program. At the same time they also correlate with learners' needs and ascertain to produce the desired learning outcomes. In order to advance a teaching program towards success, educators need to be very careful in the process of selection and gradation of the materials.

Materials are important tools as they are the chief means to achieve the aims and objectives of a teaching program. They should be tailored to the learners' needs to ensure the best outcome for the desired goal. Selecting or sequencing the materials in language teaching should be based on the students' needs, background knowledge and objectives of a particular academic program. They should be suitable in all respects. Suitability, in the sense of finding materials that are comfortable and familiar to the students, is another tool to achieve the target outcome of a particular program. There may be some queries like: are the materials used compatible with learners' level? Are the materials within the area of comprehension level of learners? Are the materials interesting and relevant? Sometimes a text which seems to be appropriate will turn out to be very difficult to implement when we introduce it to the class. One example of this situation is provided by Fujwara (1996). She describes a situation in which a text that seemed right in achieving the purpose of the course, developing listening skills and strategies, was in practice too difficult for the students (as cited in Marand, 2011). Therefore, materials are chosen for subjective reasons, and can only be adopted as standard after some experience in the classroom. It is also certain that materials will keep on changing from time to time as per the needs of learners. In order to apply the constant changes in academic and professional disciplines effectively, the department needs to review the process of selection and grading of teaching materials in order to meet the desired goals. Rubin (1975) says "good language learning depends on at least three variables - aptitude, motivation, and opportunity" (p. 42). Opportunity according to him includes all teaching materials which provide an opportunity to learn a language as well as practice. The present research is inspired by the same fact and thus takes into account the continual experiment with new materials for the second level English courses at the PYP, Najran University. This study investigates the factors responsible for continual change of English materials used in the second level English courses. This study intends to offer some measures to be taken into consideration while selecting and grading the materials for the desired goal. 


\section{Literature Review}

Litz (2005) asserts that there are many important elements in the practice of English language teaching environment but the materials and instructional materials are the most essential parts that the language instructor frequently use in many EFL/ESL classroom. Hutchinson \& Torres (1994) suggest that:

the materials is an almost universal element of [English Language] teaching. Millions of copies are solid every year, and numerous aid projects have been set up to produce them in [various] countries... No teaching learning situation, it seems, is complete until it has its relevant materials. (p. 315)

Hence, the materials serve as a wheel of a teaching and learning program for both teachers and students. Materials are key elements in English language teaching and learning situation, they also offer other many advantages for both teachers and learners when we use them in EFL/ ESL classroom situation. As Hycroft (1998), shows that one of the main advantages of materials in [a Language] classroom situation is that the students' progress and achievement can be measured correctly when we use them. Sheldon (1988) also observed that many of the students believe that published materials are more reliable and trustworthy than teacher-produced materials. Therefore, in order to maintain the suitability, selection and gradation of EFL/ESL materials for a particular group of learner in a particular social/ cultural context is necessary. Graves (1996) illustrates that teachers consider different factors in selecting and grading the materials. The author emphasizes that appropriateness includes student comfort and familiarity with the materials, language level, interest, and relevance. Materials are selected and sequenced for different reasons. Madsen \& Bowen (1978) mention that materials are selected and graded in order to achieve "congruence" (as cited in Marand, 2011).

According to Cunningsworth (1995, p. 136), every teaching-learning situation is unique due to some factors such as: (1) the dynamics of the classroom, (2) the personalities involved, (3) the constraints imposed by the syllabus, (4) the availability of resources, and (5) the expectation and motivation of the learners.

Harmer (1983) developed very effective and comprehensive criteria of evaluative framework to evaluate EFL/ESL materials. In his criteria, he discussed three stages to understand the target group. The three stages are: (1) learners' personality who are they and what they bring to class, their age, sex, social/cultural background, their occupation, their motivation and attitude, educational background, knowledge of English and their interests and belief, (2) what are the learners' needs, when are they going to use English and what skills they should learn, and (3) appropriate materials according to the need of learners.

Harmer (1983) suggests two main stages to evaluate EFL/ESL materials or materials. These two stages are as follow:

1). To study whether the EFL Materials are compatible with the learners' needs.

2). To pilot the materials on a small group of learners and measure the result before taking decisions to use the materials.

Harmer (1983) established an effective "materials evaluation form" in seven perspectives:

1) Practical consideration

2) Layout and design

3) Subject and content

4) Language type

5) Skills

6) Activities

7) Guidance

Under the practical consideration may refer to the price of the materials, its availability, whether it contains a workbook, CDs/DVDs, teacher's book etc. The "layout and design"-material should be visually convenient and attractive to learners. The subject and content and language should be appropriately related to learners' background, needs and interests. There should be a balance between different skills and activities. Whether there is a Proper guidance for both students and teachers in the materials.

Habtoor (2012) stated:

since materials in Saudi universities are not produced by the university teachers themselves, especially in ELT, the teachers have to select their own materials. Accordingly, there are several materials produced annually across the globe and this wide range of materials designed mainly for ESL/EFL situations. This 
variation leads to some confusion among teachers, especially those with little or no experience. Even experienced teachers might find it a daunting task to select materials for their target groups. (p. 46)

Chambers (1997) says, "Selection of materials to be used jointly in an ELT class should be selected by as wide range of users as possible. This is likely to increase the sense of ownership of the decision". Brown (1995) defined evaluation as "the systematic collection and analysis of relevant information necessary to promote the improvement of the curriculum and assess its effectiveness within the context of a particular institution involved" (p. 24).

Sheldon (1988) has offered several reasons for materials evaluation. He suggests that the selection of an ELT materials often signals an important administrative and educational decision in which there is considerable professional, financial, or even political investment. A thorough evaluation, therefore, would enable the managerial and teaching staff of a specific institution or organization to discriminate between all of the available materials in the market. (as cited in Habtoor, 212, p. 47)

Al-Saif (2005) says, "while materials are central to how EFL teaching is done in Saudi Arabia, there is much need for an evaluation of their content and to investigate their role in teaching practice and methodology" (p. 7). This study particularly emphasizes the factors responsible for changing materials used in English Language at PYP. It also sheds light on the extent this constant change of materials affects the goal of the PYP. Moreover, the study recommends some possible measures which should be taken into consideration while selecting and grading the materials to achieve the desired goal.

\section{Research Objectives}

1). To find out the various factors responsible for the constant change in the second level English materials

2). To recommend measures while selecting and grading the materials to achieve the desired goal

\section{Research Methodology}

As far as the current study is concerned, the researchers found the Interview and Questionnaire Survey as suitable research methods. The participants in this study were 15 teachers. The present study used both Qualitative and Quantitative methods of data analysis by employing two tools, namely interview and questionnaire.

\section{Results and Discussion}

This section presents the results, analysis, and interpretation of data which were extracted from the tools used in this study. The tools utilized to collect the data and to find out the various factors responsible for the constant change in the second level English materials were: teacher questionnaire and semi-structured interview. Considering the importance of selecting and grading the materials (Litz, 2005;Hycroft, 1998; Graves, 1996; Marand, 2011; Harmer, 1983; Chambers, 1997), this study analyzed the collected data using simple excel and SPSS. The results were as follows:

\subsection{Various Purposes of Using English for Level 2 Students}

Table 1. Various purposes of using English

\begin{tabular}{|c|c|c|c|c|c|c|}
\hline & Cases & & & & & \\
\hline & Valid & & Missing & & Total & \\
\hline & $\mathrm{N}$ & Percent & $\mathrm{N}$ & Percent & $\mathrm{N}$ & Percent \\
\hline \$Needs_English(a) & 15 & $100.0 \%$ & 0 & $.0 \%$ & 15 & $100.0 \%$ \\
\hline
\end{tabular}

Note. a. Dichotomy group tabulated at value 1 . 
Table 2. \$ Needs_English frequencies

\begin{tabular}{lllll}
\hline & & \multicolumn{2}{l}{ Responses } & \multicolumn{2}{l}{ Percent of Cases } \\
& & $\mathrm{N}$ & Percent & $\mathrm{N}$ \\
\hline \multirow{2}{*}{ \$ Needs_English(a) } & OPTION 1: To pursue higher education in KSA & 11 & $12.0 \%$ & $73.3 \%$ \\
& OPTION 2: To read technical books/articles & 10 & $10.9 \%$ & $66.7 \%$ \\
& OPTION 3: To fill in various forms & 7 & $8.6 \%$ & $46.7 \%$ \\
& OPTION 4: To write CV and cover letter & 6 & $6.5 \%$ & $40.0 \%$ \\
& OPTION 5: To write scientific report & 7 & $7.6 \%$ & $46.7 \%$ \\
& OPTION 6: To appear in job interviews & 5 & $5.4 \%$ & $33.3 \%$ \\
& OPTION 7: To work in Saudi Arabia & 4 & $4.3 \%$ & $26.7 \%$ \\
& OPTION 8: To write official/formal letters & 7 & $7.6 \%$ & $46.7 \%$ \\
& OPTION 9: To study abroad & 13 & $14.1 \%$ & $86.7 \%$ \\
& OPTION 10: To work abroad & 8 & $8.7 \%$ & $53.3 \%$ \\
& OPTION 11: To live abroad & 6 & $6.5 \%$ & $40.0 \%$ \\
& OPTION 12: To use internet and mobile phones & 8 & $8.7 \%$ & $53.3 \%$ \\
\hline Total & & 92 & $100.0 \%$ & $613.3 \%$ \\
\hline
\end{tabular}

Note. a. Dichotomy group tabulated at value 1.

As depicted in the tables 1 and 2, 15 out of 15 respondents chose at least one of the options, and no option was missed. The total of the checked options in all 12 categories was 92 . That is an average of slightly more than 6 per respondent. It appears that students of level-2 need English at various levels, and it is not surprising that OPTION 9 has the highest score; $86.7 \%$ of the respondents chose it. This option has a frequency of $14.1 \%$ as far as the response percentage is concerned.

\subsection{The General Objective of Learning English for Level-2 Students}
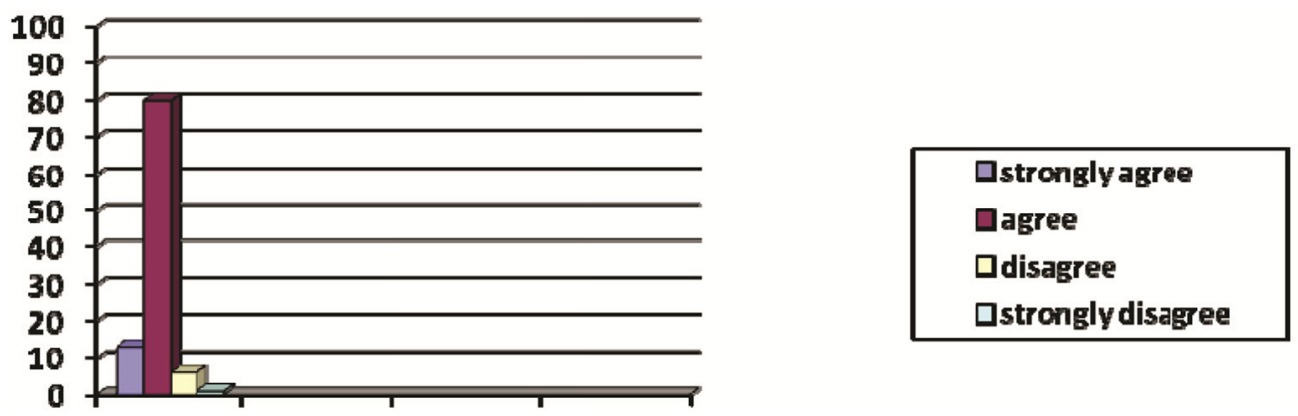

Figure 1. The general objective of learning English

As depicted in figure 1, 13\% respondents strongly agree with the statement. Majority of them i.e. $80 \%$ agree with the statement that the general objective of learning English for the students of Level 2 is to be able to use language effectively in EFL situations, while $6 \%$ decided to disagree followed by only $1 \%$ as strongly disagree.

\subsection{The Specific Objective of Learning English for Level-2 Students}

Table 3. Specific objective of learning English

\begin{tabular}{lllllll}
\hline & Cases & & \multicolumn{2}{c}{} & & \multicolumn{2}{c}{ Total } \\
& Valid & & Missing & & \\
& $\mathrm{N}$ & Percent & $\mathrm{N}$ & Percent & $\mathrm{N}$ & Percent \\
\hline SObjectives_learning_English(a) & 15 & $100.0 \%$ & 0 & $.0 \%$ & 15 & $100.0 \%$ \\
\hline
\end{tabular}

Note. a. Dichotomy group tabulated at value 1. 
Table 4. \$ Objectives_learning_English frequencies

\begin{tabular}{|c|c|c|c|c|}
\hline & & \multicolumn{2}{|c|}{ Responses } & \multirow{2}{*}{$\begin{array}{l}\text { Percent of Cases } \\
\mathrm{N}\end{array}$} \\
\hline & & $\mathrm{N}$ & Percent & \\
\hline $\begin{array}{l}\text { \$Objectives } \\
\text { learning }\end{array}$ & $\begin{array}{l}\text { OPTION1 to read and understand the course material of professional } \\
\text { disciplines }\end{array}$ & 14 & $26.9 \%$ & $93.3 \%$ \\
\hline \multirow[t]{5}{*}{ _English(a) } & $\begin{array}{l}\text { OPTION2 to write assignments, examinations, technical report, } \\
\text { research project report, applications, and official letters }\end{array}$ & 10 & $19.2 \%$ & $66.7 \%$ \\
\hline & OPTON3 to understand the class lectures & 12 & $23.1 \%$ & $80.0 \%$ \\
\hline & $\begin{array}{l}\text { OPTION4 to participate actively in the seminars, workshops, } \\
\text { symposium etc. }\end{array}$ & 4 & $7.7 \%$ & $26.7 \%$ \\
\hline & OPTION5 to use the language effectively & 8 & $15.4 \%$ & $53.3 \%$ \\
\hline & OPTION6 to become a confident language user & 4 & $7.7 \%$ & $26.7 \%$ \\
\hline Total & & 52 & $100.0 \%$ & $346.7 \%$ \\
\hline
\end{tabular}

Note. a. Dichotomy group tabulated at value 1.

As depicted in the tables 3 and 4, 15 out of 15 respondents chose at least one of the options, and no option was missed. The total of the checked options in all 6 categories was 52. That is an average of more than 3 per respondent. It appears that students have some specific objectives of leaning English as presented, and it is not surprising that OPTION 1 has the highest score; $93.3 \%$ of the respondents chose it. This option has a frequency of $26.9 \%$ as far as the response percentage is concerned.

5.4 How Do You Rate Level-2 Materials in Respect to Above Objectives?
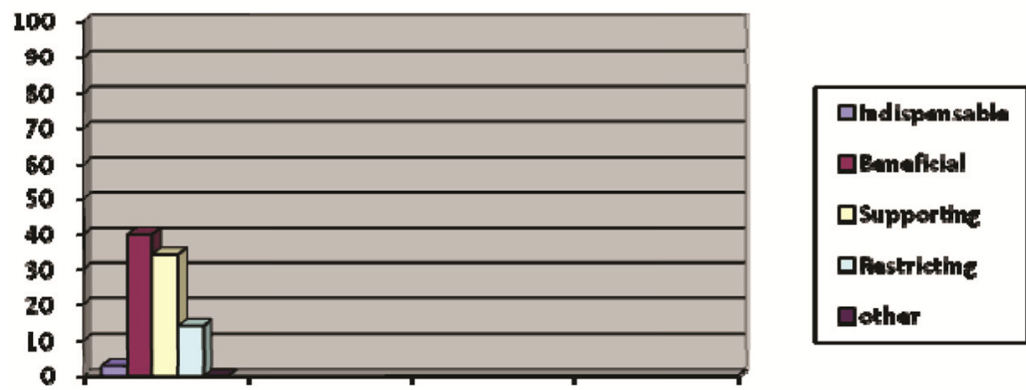

Figure 2. Level-2 materials in respect to objectives

As shown in figure 2, 3\% respondents regard L2 materials as indispensable. $40 \%$ consider L2 materials in respect to course objectives as beneficial, while $34 \%$ see the L2 materials as supporting, while $14 \%$ register their concern and regard their opinion for the L2 materials as restricting.

\subsection{The Current Materials Help Effectively to Fulfill the Objectives of Learning English for Students of Level-2}
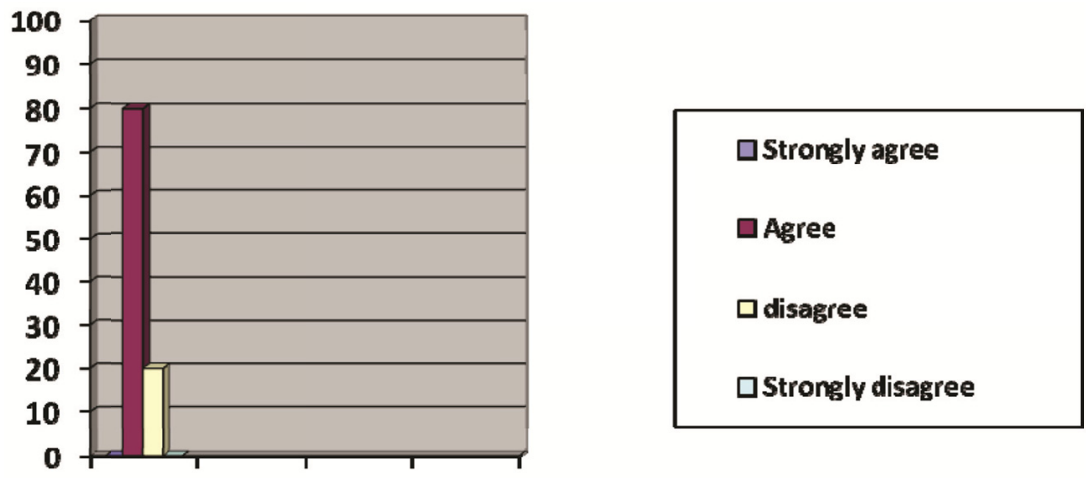

Figure 3. Materials effectiveness and objectives of learning English 
As shown in figure 3, $80 \%$ respondents agree with the statement, while $20 \%$ decided to disagree with the statement that the current materials helps effectively to fulfill the objectives of learning English for students of level-2.

\subsection{What Were the Reasons to Change the Previous Materials of Level-2 Students? [Tick One or More]}

Table 5. Reasons to change the previous materials

\begin{tabular}{lllllll}
\hline & \multicolumn{2}{c}{ Cases } & & & \multicolumn{2}{c}{ Total } \\
& Valid & & Missing & Percent & N & Percent \\
& $\mathrm{N}$ & Percent & $\mathrm{N}$ & $.0 \%$ & 15 & $100.0 \%$ \\
\hline SReasons_Change_Materials(a) & 15 & $100.0 \%$ & 0 & &
\end{tabular}

Note. a. Dichotomy group tabulated at value 1.

Table 6. \$Reasons_Change_Materials frequencies

\begin{tabular}{lllll}
\hline & & \multicolumn{2}{l}{ Responses } & \multicolumn{2}{l}{ Percent of Cases } \\
& & $\mathrm{N}$ & Percent & $\mathrm{N}$ \\
\hline $\begin{array}{l}\text { \$Reasons_ } \\
\text { Change_- }\end{array}$ & $\begin{array}{l}\text { OPTION1 The contents were not appropriately organized } \\
\text { Materials (a) }\end{array}$ & 5 & $15.2 \%$ & $33.3 \%$ \\
& $\begin{array}{l}\text { OPTION2 The contents were not compatible with the course } \\
\text { objective } \\
\text { OPTON3 The materials was above to the level of the students } \\
\text { OPTION4 The materials was not appropriately selected and } \\
\text { graded as per the learners' needs. }\end{array}$ & 5 & $15.2 \%$ & $33.3 \%$ \\
& $\begin{array}{l}\text { OPTION5 They didn't have enough vocabulary support for } \\
\text { writing }\end{array}$ & 5 & $21.2 \%$ & $46.7 \%$ \\
& $\begin{array}{l}\text { OPTION6The lessons and the exercises were not useful as per } \\
\text { the learners' needs }\end{array}$ & 6 & $15.2 \%$ & $33.3 \%$ \\
\hline Total & & 33 & $18.2 \%$ & $40.0 \%$ \\
\hline
\end{tabular}

Note. a. Dichotomy group tabulated at value 1.

As depicted in the tables 5 and 6,15 out of 15 respondents chose at least one of the options, and no option was missed. The total of the checked options in all 6 categories was 33. That is an average of slightly more than 2 per respondent. It appears that respondents agree with the reasons to change the previous materials as presented, and it is not surprising that OPTION 4 has the highest score; $46.7 \%$ of the respondents chose it. This option has a frequency of $21.2 \%$ as far as the response percentage is concerned.

\subsubsection{There Have Been Inconsistencies in the Level-2 English Materials}
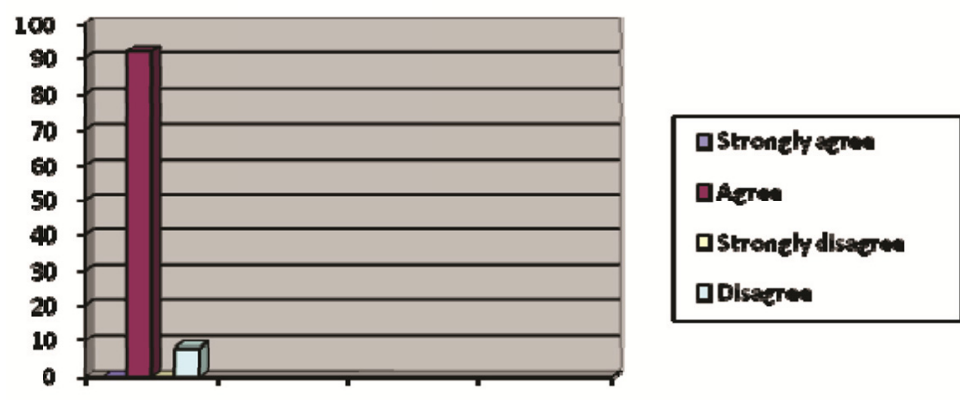

Figure 4. Inconsistencies in English materials

As shown in figure $4,92 \%$ respondents agree with the statement, while $8 \%$ decided to disagree with the statement that there have been inconsistencies in the level-2 English material. 


\subsubsection{There Have Been Inconsistencies in Level-2 English Materials}

Table 7. Reasons for inconsistencies in level-2 English materials

\begin{tabular}{lllllll}
\hline & Cases & & & & \multicolumn{2}{c}{ Total } \\
& Valid & & Missing & & \\
& $\mathrm{N}$ & Percent & $\mathrm{N}$ & Percent & $\mathrm{N}$ & Percent \\
\hline SInconsistencies_Materials(a) & 15 & $100.0 \%$ & 0 & $.0 \%$ & 15 & $100.0 \%$ \\
\hline
\end{tabular}

Note. a. Dichotomy group tabulated at value 1 .

Table 8. \$Inconsistencies_Materials frequencies

\begin{tabular}{|c|c|c|c|c|}
\hline & & \multicolumn{2}{|c|}{ Responses } & \multirow{2}{*}{$\begin{array}{l}\text { Percent of Cases } \\
\mathrm{N}\end{array}$} \\
\hline & & $\mathrm{N}$ & Percent & \\
\hline \multirow[t]{6}{*}{$\begin{array}{l}\text { \$Inconsistencies_ } \\
\text { Materials(a) }\end{array}$} & $\begin{array}{l}\text { OPTION1 The materials do not cater the student's learning } \\
\text { outcomes in the short term and long term }\end{array}$ & 8 & $25.0 \%$ & $53.3 \%$ \\
\hline & OPTION2 The materials are not up to the level of students & 8 & $25.0 \%$ & $53.3 \%$ \\
\hline & OPTON3 The contents are culturally unfamiliar to students & 5 & $15.6 \%$ & $33.3 \%$ \\
\hline & OPTION4 The contents in the materials are dull and boring & 1 & $3.1 \%$ & $6.7 \%$ \\
\hline & $\begin{array}{l}\text { OPTION5 The materials don't provide enough language } \\
\text { practice to students }\end{array}$ & 6 & $18.8 \%$ & $40.0 \%$ \\
\hline & $\begin{array}{l}\text { OPTION6 The exercises in the materials are not learner } \\
\text { centered }\end{array}$ & 4 & $12.5 \%$ & $26.7 \%$ \\
\hline Total & & 32 & $100.0 \%$ & $213.3 \%$ \\
\hline
\end{tabular}

Note. a. Dichotomy group tabulated at value 1 .

As depicted in the tables 7 and 8,15 out of 15 respondents chose at least one of the options, and no option was missed. The total of the checked options in all 6 categories was 32 . That is an average of slightly more than 2 per respondent. It appears that the respondents agree with the inconsistencies in level-2 English materials, as presented, and it is not surprising that OPTIONS 1 and 2 have the highest score; $53.3 \%$ of the respondents chose them. These options have a frequency of $25 \%$ each as far as the response percentage is concerned.

\subsection{To What Extent Are the Materials Useful Imparting the Necessary Skills?}

(Scale: 1 is for least useful and 5 is for the most useful)
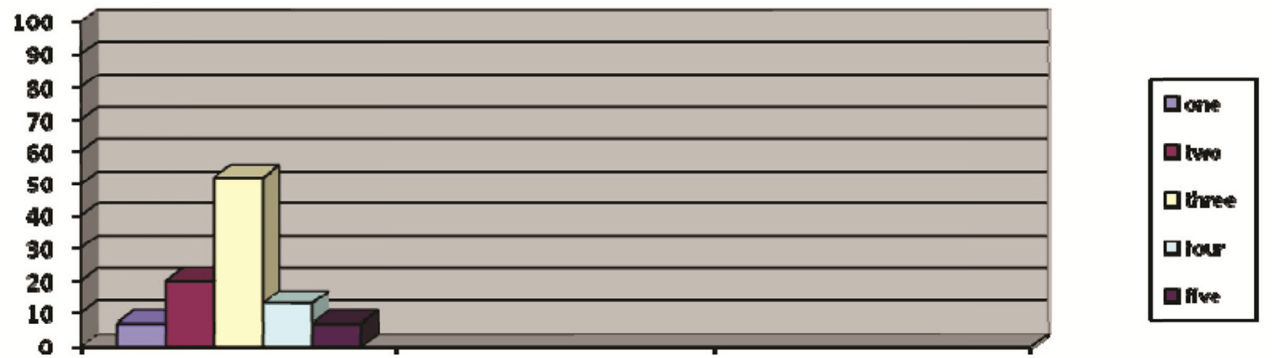

Figure 5. Materials usefulness in imparting the necessary skills

As shown in figure 5, 7\% consider the materials as least useful imparting the necessary skills. $20 \%$ consider the materials as somewhat useful imparting the necessary skills. $52 \%$ consider the materials as useful imparting the necessary skills. $13 \%$ consider the materials as very useful imparting the necessary skills, while $7 \%$ consider the materials as most useful imparting the necessary skills.

\subsection{To What Extent Students Get the Materials Motivating?}

(Scale: 1 is for least useful and 5 is for most useful) 

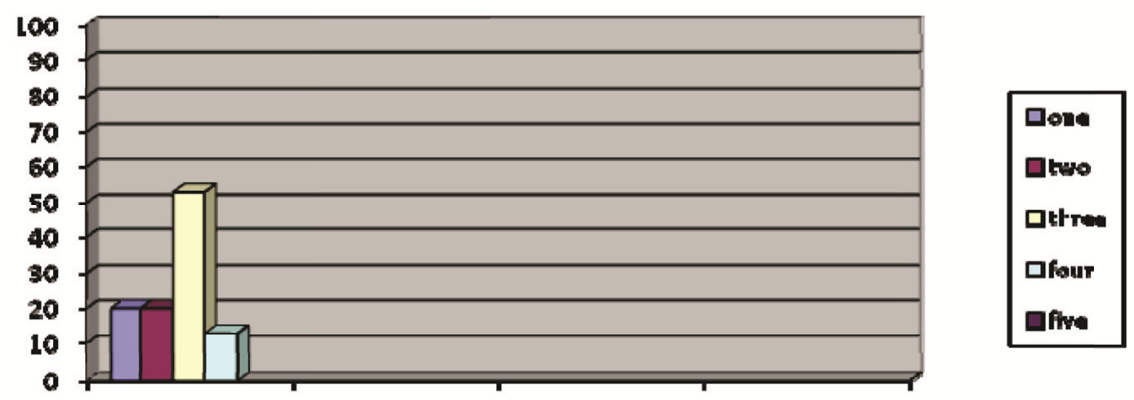

Figure 6. Materials and motivation

As shown in figure 6, 20\% consider the materials as least motivating for students. $20 \%$ consider the materials as somewhat motivating for students. $53 \%$ consider the materials as motivating for students, while $13 \%$ consider the materials very motivating for students.

\subsection{Have You Ever Been Involved in Selecting the Level-2 Materials?}
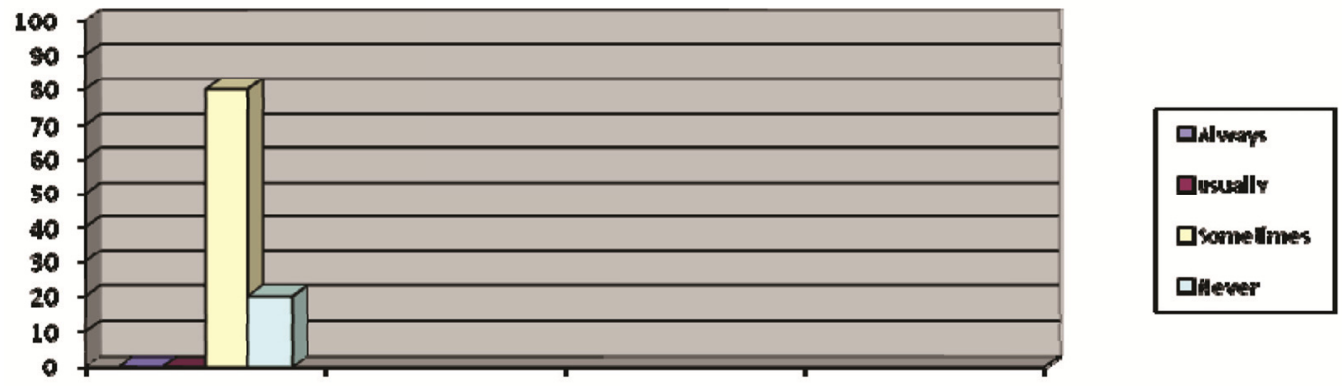

Figure 7. Involvement in selecting the level-2 materials

As shown in figure 7, none of the respondents chose to their opinion for the first two categories i.e. always and usually, while $80 \%$ respondents consider that they were sometimes involved in selecting the level 2 materials followed by $20 \%$ respondents who were never involved in selecting the level 2 materials.

\section{Semi Structured Interview Questions}

\subsection{What Are the Various Factors Responsible for the Constant Change in the Second Level English Materials at the Preparatory Year, Najran University?}

\section{Factors:}

The participants pointed out the following factors responsible for the constant change in the second level English materials at the Preparatory Year, Najran University:
1) Lack of proper planning
2) Incompatibility between students and materials level
3) Change in the curriculum without the student needs analysis
4) Poor students background and current materials level
5) Rare language contents exposure (beyond classroom)
6) Excessive availability of readymade materials in the local market
7) Incompetent human resource on the curriculum review/evaluation committee
8) Lack of availability of proper and appropriate of materials in the local market
9) Previously selected materials are improper and inappropriate
10) Overlook of cultural and ethical aspects while selection and gradation 
5.11 What Are the Measures to Be Taken into Consideration While Selecting and Grading the Materials to Achieve the Desired Goal?

\section{Measures:}

The participants suggested the following measures be taken into consideration while selecting and grading the materials to achieve the desired goal:

1) Students' needs analysis

2) Syllabus to be covered vs. credit/contact hours

3) Curriculum objectives vs. students need

4) Compatibility between students and materials level

5) Compatibility between curriculum contents and students' need

6) Students' language proficiency be taken into account

7) Curriculum contents should be based on real life situations

8) Competent human resource on the curriculum review/evaluation committee

9) Standards and criteria to be followed for selection and gradation

10) Compare and contrast criteria should be followed for $S \& G$

\section{Conclusion}

The findings of the study revealed that $86.7 \%$ of the respondents believed that students need English to study abroad. However, $73 \%$ respondents believed that students need English to pursue higher education in Saudi Arabia followed by a relative percentage believed that they needed English to read technical books/articles. The findings of this study also indicated that $80 \%$ respondents agreed that the general objective of learning English is to be able to use language effectively in EFL situations, while for the specific objective of learning English, the majority of the respondents believed that it is to read and understand the course materials of professional disciplines and to understand the class lectures. The respondents, however, agreed with the compatibility of the materials and their objectives. Regarding the reasons to change the materials, the findings of this study showed that $46 \%$ respondents believed that the materials were not appropriately selected and graded as per learners' needs. While $40 \%$ respondents believed that the lessons and the exercises were not useful as per learners' needs. As a result, there have been inconsistencies in the materials, as believed by $92 \%$ of the respondents, because majority of the respondents agreed that the materials did not cater the student's learning outcomes in the short term and long term and were not up to the level of students. Regarding the materials' usefulness, the respondents considered the materials as useful to impart necessary skills and motivating for students contradicted with their previous opinion where majority believed that the materials did not cater the student's learning outcomes and needed to be changed. However, as shown in the data, majority of the participants contributed in the materials selection and gradation procedure.

\section{Recommendations}

Instructional materials are essential tools in English language classroom. They allow students to interact with words, images, and ideas in ways that develop their abilities in reading, listening, speaking, writing, and other linguistic and communicative purposes. The researchers, based on the data results, propose that stake holders should follow a well-defined and standard process for the selection and gradation of English materials keeping the fact in mind that the materials meet students' needs and their comprehension level. This study, however, further recommends that the stakeholders should ensure that the materials are aligned with the curriculum goals and objectives of the PYP in general, and English program in particular. They must be selected and graded with an expertise of establishing a connection within and between students' levels, courses, and their future needs. In addition, the following steps are recommended to ensure that the materials selection and gradation process witnesses:

1). a meet with "professionals" who hold curriculum design and materials development portfolio.

2). a symposium with the concerned faculty on the target audience, needs analysis and implications of materials in terms of strengths and weaknesses.

3). a compare and contrast exercise with available authentic and relevant materials using different materials evaluation checklists (Tucker, 1975; Sheldon, 1988; Cunninsworth, 1995; Ur, 1996).

It is worth quoting here. 
“...it is, in principle, not possible to find materials which would interest everyone. It follows that the emphasis should be moved from attempting to provide intrinsically interesting materials, which we have just claimed is generally impossible, to doing interesting things with materials ... these materials should be chosen, not so much on the basis of their own interest, but for what they can be used to do" (Brown \& Yule, 1983, p. 83).

\section{Acknowledgement}

This research has been funded by the Deanship of Scientific Research (Grant No. NU/SHED/13/076), Najran University, Saudi Arabia.

\section{References}

Allwright, R. (1982). What Do We Want Teaching Materials For? ELT Journal, 36(1).

Alptekin, C. (1993). Target-Language Culture in EFL Materials. ELT Journal, 47. https://doi.org/10.1093/elt/47.2.136

Al-Saif, A. (2005). The motivating and inhibiting factor affecting the use of web-based instruction at the University of Qassim in Saudi Arabia. Unpublished PhD thesis. Wayne State University.

Alshumaimeri, Y., \& Alghamdi, F. (2009). Perceptions of Saudi PYP students about the IEP at King Saud University. Research paper presented at IATEFL 43rd Annual Conference, 31 March, 4th April, Cardiff 2009, UK.

Brown, G., \& Yule, G. (1983). Discourse Analysis. Cambridge: Cambridge University Press. https://doi.org/10.1017/CBO9780511805226

Brown, J. D. (1995). The elements of language curriculum: A systematic approach to program development. Boston: Heinle and Heinle Publishers.

Carroll, D., \& Kowitz, J. (1994). Using concordancing techniques to study gender stereotyping in ELT materials. In J. Sunderland (Ed.), Exploring Gender: Questions and Implications for English Language Education. Hemel Hempstead: Prentice Hall.

Chambers, F. (1997). Seeking consensus in materials evaluation. ELT Journal, 51(1), 29-35. http://dx.doi.org/10.1093/elt/51.1.29

Cunningsworth, A. (1995). Choosing your course book. Oxford: Macmillan Heinemann.

Florent, J., \& Walter, C. (1989). A Better Role for Women in TEFL. ELT Journal, 43(3). https://doi.org/10.1093/elt/43.3.180

Graves, K. (1996). Teachers as course developers. Cambridge: CUP. https://doi.org/10.1017/CBO9780511551178

Habtoor, H. A. (2012). English for Specific Purpose Materials in EFL Milieu: An Instructor's Perspective Evaluation. International Journal of Linguistics. https://doi.org/10.5296/ijl.v4i3.1732

Harmer, J. (1983). The Practice of English Language Teaching. London: Longman. https://doi.org/10.1093/elt/37.2.184

Hutchinson, T., \& Torres, E. (1994). The Materials as Agent of Change. ELT Journal, 48(4). https://doi.org/10.1093/elt/48.4.315

Hycroft, J. (1998). An Introduction to English Language Teaching. London: Longman.

Litz, D. R. (2005). Materials Evaluation and ELT Management: A South Korean Case Study. The Asian EFL Journal. Retrieved from http://www.asian-efl-journal.com

Marand, E. S. (2011). Adoption, Adaptation, and Development of Language Instructional Units. Retrieved from http://arzek.weebly.com/uploads/1/2/9/1/12914289/adopt_n_adapt.pdf

Munby, J. (1978). Communicative Syllabus Design. Cambridge: Cambridge University Press.

O'Neill, R. (1982). Why use materials? ELT Journal, 36(2). Oxford: Oxford University Press. https://doi.org/10.1093/elt/36.2.104

Porecca, K. (1984). Sexism in Current ESL Materials. TESOL Quarterly, 18(4). https://doi.org/10.2307/3586584

Prodromou, L. (1988). English as Cultural Action. ELT Journal, 42(2). https://doi.org/10.1093/elt/42.2.73 
Rubin, J. (1975). What the "Good Language Learner" can teach us? TESOL Quarterly, 9(1), 42. https://doi.org/10.2307/3586011

Sheldon, L. (1988). Evaluating ELT Materials and Materials. ELT Journal, 42(2). Stereotyping in ELT Materials' In J. Sunderland (Ed.), Exploring Gender: Questions and Implications for English Language Education. Upper Saddle River, NJ: Prentice Hall International.

Sheldon, L. (1988). Evaluating ELT materials and materials. ELT Journal, 42(4). https://doi.org/10.1093/elt/42.4.237

Tucker, C. A. (1975). Evaluating beginning materials. English Teaching Forum, 13.

Ur, P. (1996). A Course in Language Teaching Practice and Theory. Cambridge: Cambridge University Press.

Widdowson, H. G. (1978). Teaching Language as Communication. Oxford: Oxford University Press.

\section{Copyrights}

Copyright for this article is retained by the author(s), with first publication rights granted to the journal.

This is an open-access article distributed under the terms and conditions of the Creative Commons Attribution license (http://creativecommons.org/licenses/by/4.0/). 